\title{
COMPARISON OF SYSTEMS OF CARS FOR EXTREME CONDITIONS LOGGING
}

\author{
Alexander Yurievich Shirnin \\ Volga State University of Technology, Russian Federation \\ Yuri Aleksandrovich Shirnin \\ Volga State University of Technology, Russian Federation
}

Technological schemes for development of cutting areas in extreme conditions which basis the combined way of skidding is are submitted. Systems of cars for development of cutting areas in such conditions are offered this way. Comparison of the technological processes which are carried out by these systems of cars by the following criteria is carried out: level of mechanization of work, expense of time for preparation of $1 \mathrm{~m}^{3}$, coefficient of environmental friendliness of the technological scheme, power consumption.

Keywords: combined hauling wood; the evaluation criteria of technological processes.

\section{INTRODUCTION}

World development of forest exploitation multidirectional vectors tend. So the areas of forest plantings tend prompt reduction. High-quality, readily available forest stands are cut down first of all. However such combination becomes less than [9].

The world forest mechanical engineering has an increase in production vector generally due to release of high-performance expensive logging cars. The positive moment of such aspiration is release of lumberers from a hard work. The negative moments are increase of energy consumption, serious ecological consequences for territories of cuttings down [6].

In this regard forest exploitation development vector aside difficult available territories: rehumidified, windfall, with the crossed surface, remote from transport ways, etc. has very essential value.

Earlier it was proved that in extreme conditions of logging it is expedient to apply the combined skidding of wood [9] representing a combination of winch and tractor skidding which provides reduction of forest strip skidding trail and frequency of movement on them logging cars. It is necessary to understand conditions of logging as the extreme, at which: danger of receiving injuries by the personnel of workers increases; load of elements of processing equipment increases; there are obstacles significantly reducing passability and productivity of lesosechny cars; use of standard technological schemes of development of cutting areas is impossible; receiving qualitative production, etc. is difficult. For the ways and devices for realization of the combined skidding a number of patents [2, 3] are received.

\section{Work purpose}

To prove criteria of comparison, to calculate their values and by results of calculation to estimate systems of cars for the combined way of skidding in extreme conditions.

\section{The solved tasks}

1. To create systems of cars;

2. To prove and define numerical values of criteria of an assessment of technological processes for the presented systems of cars;

3. To carry out the comparative analysis on the found values and to make the conclusion about expediency of use of systems of cars taking into account natural working conditions.

Three options of systems of cars for the combined way of skidding in extreme conditions are created.

The system of cars No. 1 (figure 1, a) consists from: the feller-buncher (FB) 1 consisting of the power module (PM) with the manipulator and the gripping and cutting device (GCD); the skidding car 2 including EM and the technological module (TM) with the winch for wood subskidding; the delimbing-bucking machine (DBM) 3 including EM and TM with the processor; the skidding car for assortments 4 including EM and TM with 
a cargo compartment. On positions 2, 3, 4 EM are interchangeable, that is in the absence of a raw materials stock, for example, assortments of EM carries out skidding by the wood winch (poses. 2).

As the power module for systems of cars it is possible to use, for example, the MПР-371 [10] car which has the manipulator with a rotary col- umn and clamshell capture. As working body of the manipulator depending on operation except clamshell capture GCD will be used.

In system of cars No. 2 (fig. 1, b) unlike system No. 1 instead of DBM petrol saws: for cutting of boughs (Bpos, poses. 2) and for a buck of switches (Bs, poses. 4).

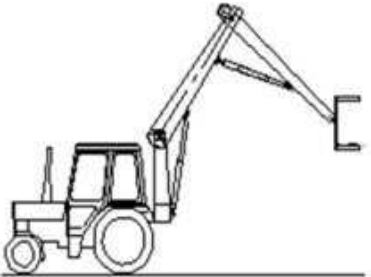

(1)

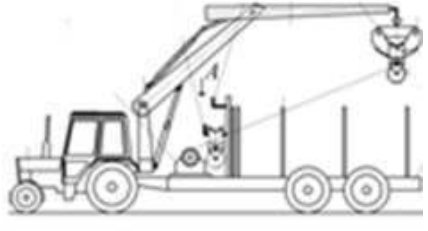

(2)

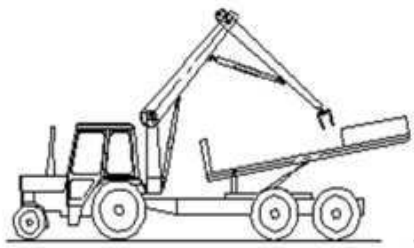

(3)

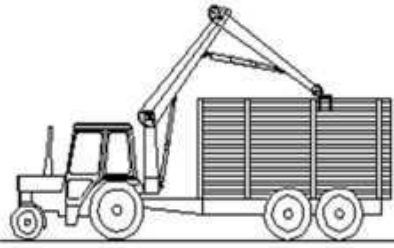

(4)

(a)

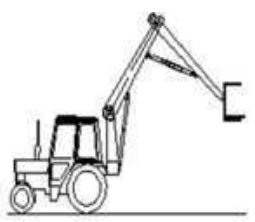

(1)

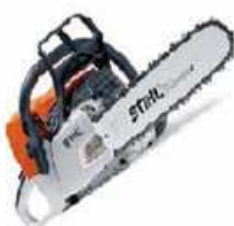

(1)

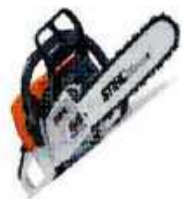

(2)

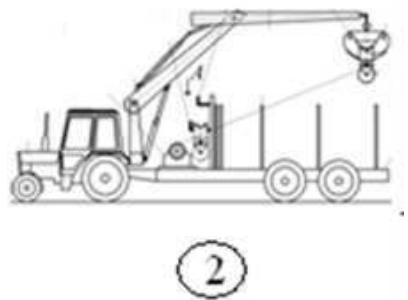

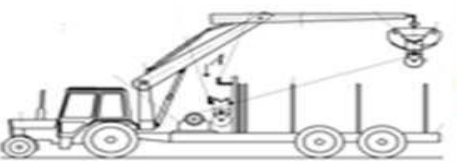

(3)

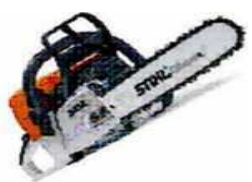

(4)

(b)

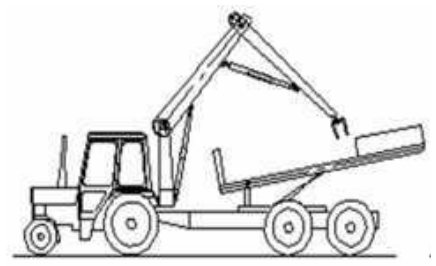

(3)

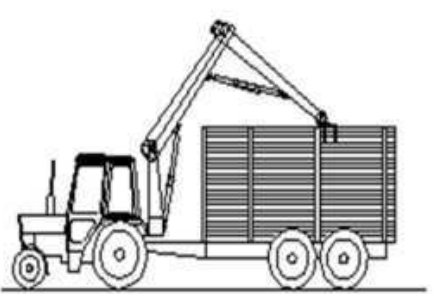

(5)

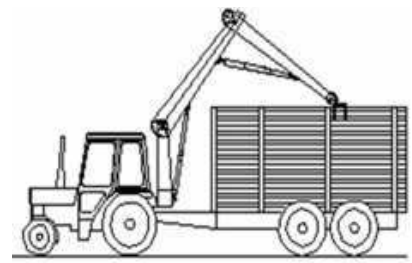

(4)

(c)

Figure 1: Systems of cars: $a-$ No. $1, b-$ No. $2, c-$ No. 3

At system of cars No. 3 (figure 1, c) unlike system No. 1 instead of FB there are one or several petrol saws on a roll of trees. On positions 2, 3, 4 the same machines, as in system No. 1 are switched on, and EM are also interchanged.

For systems of cars No. 1 and No. 2 the scheme of development of a cutting area presented in fig. 2 is offered. The cutting area 1 breaks into allotments with border 2 . In the middle of an allotment the main is split dragged 3. The allotment is broken in turn into apiaries 4 . In the middle of an apiary are marked strip trail 5 . To a roll of trees carry out FB 6 . To roll of trees carry out FB 6.

In system No. 1 the created packs of trees by the 7th car 8 for skidding by the winch move to the main I drag in a stack 9 where by means of DBM, make cutting of boughs 10 with laying them on dragged 3 and a buck of switches with laying of assortments in packs 12. Assortments by the skidding car for assortments 13 move on the top warehouse 14.

In system No. 2 trees in packs 7 are cleared of boughs by means of petrol saws. Further switches by car for skidding by the winch 8 move to the main I drag in a stack 9 where the petrol saw carries out a buck of switches 11 on assortments 12. Their skidding is made by the skidding car for assortments 13 on the top warehouse 14 . 


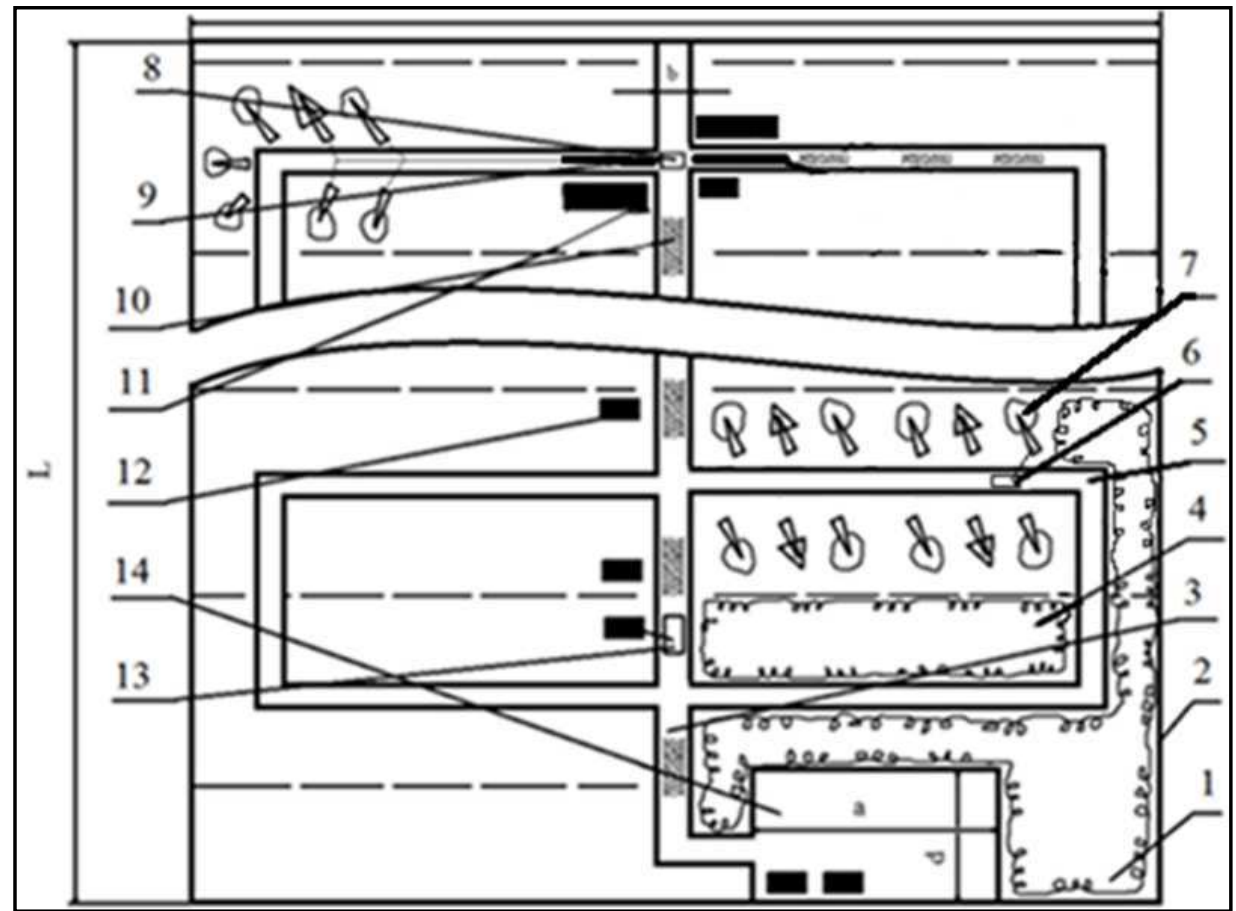

Figure 2: Technological scheme of development of a cutting area

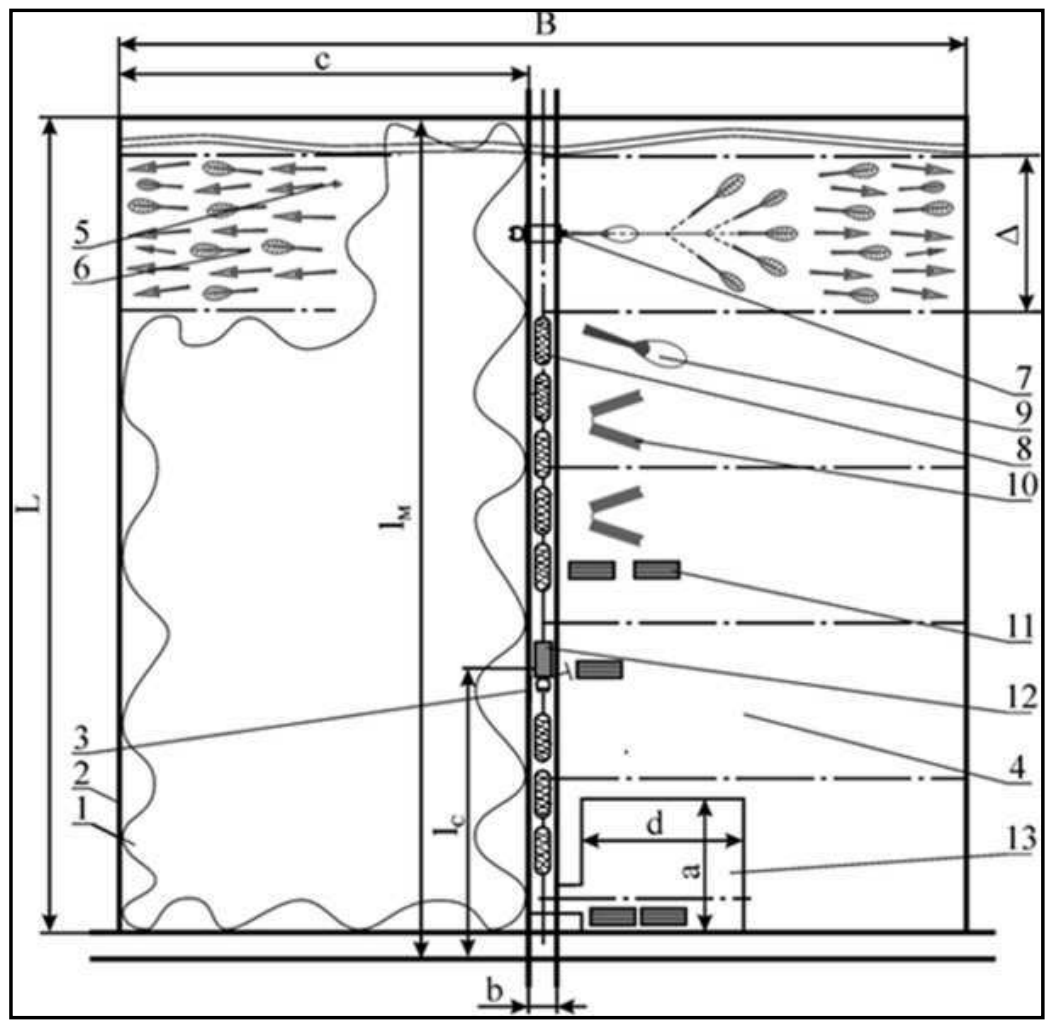

Figure 3: The scheme of development of a cutting area with the combined wood skidding

The technological scheme of development of a cutting area for system of cars No. 3 is submitted in figure 3 . The cutting area 1 breaks into allotments with border 2 . In the middle of an allotment the main is split dragged 3. The allotment is broken in turn into apiaries 4 . To a roll of trees carry out petrol saws 5 in the direction at an an- gle from the main trail. Further the tumbled-down trees 6 by means of the car for skidding by the winch 7 will mix to the main I drag in a pack 9 where by means of DBM make cutting of boughs (with laying on dragged them 8) and a buck of switches (with laying of assortments in packs 11). Their skidding is made by the skidding car for as- 
sortments 12 on the top warehouse 13 .

The complex assessment of technological processes and systems of cars is offered to be carried out by the following criteria: power consumption, environmental friendliness, work mechanization level, expenses of time for preparation of $1 \mathrm{~m}^{3}$.

Power consumption of operations of technological process is one of indicators, using which it is possible to give an objective assessment as to again created cars and existing and to analyse influence of various factors and forest vegetation conditions on productivity of cars. Thus influence of such subjective factors as qualification of the operator, technical condition of the car, quality of operational materials, etc. is excluded [01].

Technique and calculations of expenses of energy in $\mathrm{kW} \cdot \mathrm{h} / \mathrm{m} 3$, the offered systems of cars, it is stated by us in $[06,07]$.

Extent of violation of ecological functions of the wood can be estimated in coefficient of environmental friendliness [05]

where Sc - the area of a cutting area which is taken away under loading points, a trail, technologi-

$\chi=\frac{\mathrm{S}_{\mathrm{c}}}{\mathrm{S}}$

cal corridors, $\mathrm{m}^{2} ; \mathrm{S}$ - area of a cutting area, $\mathrm{m}^{2}$.

For the technological scheme (figure 2) taking into account technological corridors for movement of FB the coefficient of technological effectiveness will be determined by a formula

$$
\chi=\frac{\mathrm{b} \cdot \mathrm{L}+\mathrm{d} \cdot \mathrm{a} \cdot \mathrm{n}_{\mathrm{c}}+\mathrm{c} \cdot \mathrm{r} \cdot \mathrm{n}_{\mathrm{t}}}{\mathrm{L} \cdot \mathrm{B}}
$$

where $L-$ forest allotment length equal to length of the main skidding trail, $m(L=500 m) ; b$ - width main skidding trail, $m(b=4,5 \mathrm{~m}) ; a$ - length of upper wood-yard, $m(a=50 \mathrm{~m}) ; d-$ length and width of upper wood-yard, $m(d=20 \mathrm{~m})$; $\mathrm{n} n$ - number of upper wood-yard on a cutting area ( $n c=1) ; B-$ width forest allotment, $m(B=200 m)$ $\mathrm{c}$ - length of technological corridors, $\mathrm{m}$ ( $\mathrm{c}=$ $180 \mathrm{~m}) ; \mathrm{r}$ - width of technological corridors, $\mathrm{m}$ ( $r$ $=3 \mathrm{M}) ; \mathrm{nt}-$ number of technological corridors on a cutting area $(\mathrm{nt}=26)$.
For the technological scheme (figure 3) the area which is taken away under a preparatory work will consist of the area of the main trail: $S_{B}=b \cdot L$ and areas of loading points $-\mathrm{S} n=\mathrm{d} \cdot \mathrm{a} \cdot \mathrm{n} n$.

In this case the coefficient of environmental friendliness of the technological scheme (figure 3 ) is from expression

$\chi=\frac{(\mathrm{b} \cdot \mathrm{L}+\mathrm{d} \cdot \mathrm{a}) \cdot \mathrm{n}_{n}}{\mathrm{~L} \cdot \mathrm{B}}$

At above the given values of the parameters substituted in formulas (2) and (3) are received, environmental friendliness coefficients respectively for schemes of fig. 2 and fig. 3 are equal $X$ $=0,1729$ and $x=0,0325$.

It is necessary to understand the relation of time during which the worker (workers) operates the mechanism as the level of mechanization of work (Tm) when performing any operation (or technological process in general) by all time $(T)$, spent for performance of this operation (or technological process) $[09,10]$

$y_{m . l .}=\frac{T_{m} \cdot n_{m}}{\mathrm{~T} \cdot \mathrm{n}}$

where $\mathrm{nm}$ - number of the workers occupied on service of the mechanism (car); $n$ - number of the workers who are taking part in operation performance.

For system of cars the level of mechanization will be the sum of levels of mechanization on everyone operations and division into number of cars (mechanisms) in system (m). For example, for system of cars No. 1 the level of mechanization will be on a formula

$$
\mathrm{y}_{\mathrm{m} .1 .}=\frac{\mathrm{y}_{\mathrm{m} .1 . \mathrm{f} .}+\mathrm{y}_{\mathrm{m} \text {.1.ss. }}+\mathrm{y}_{\text {m.1.1. }}+\mathrm{y}_{\mathrm{m} \text {.1.s. }}}{\mathrm{m}}
$$

where $\mathrm{Ym}_{\mathrm{m} . \mathrm{I.f}}$ - mechanization level on a felling and log bunching; Ym.l.ss. - mechanization level on subskidding; Ym.I.I. - mechanization level on a limb chopping and bucking; Ym.l.s. - mechanization level on skidding.

As roll, cutting of boughs, a buck and skidding are carried out by cars, the level of mechanization is equal units. We determine mechanization level on subskidding

$$
\mathrm{y}_{\text {m.l.ss. }}=\frac{\mathrm{t}_{\mathrm{mc}}+\mathrm{t}_{\mathrm{d}}+\mathrm{t}_{\mathrm{ml}}+\mathrm{t}_{\mathrm{yb}}+\mathrm{t}_{\mathrm{dn}}+\mathrm{t}_{\mathrm{od}}}{2 \cdot\left(\mathrm{t}_{\mathrm{mc}}+\mathrm{t}_{\mathrm{d}}+\mathrm{t}_{\mathrm{ml}}+\mathrm{t}_{\mathrm{yb}}+\mathrm{t}_{\mathrm{rk}}+\mathrm{t}_{\mathrm{ch}}+\mathrm{t}_{\mathrm{pxk}}+\mathrm{t}_{\mathrm{cch}}+\mathrm{t}_{\mathrm{dn}}+\mathrm{t}_{\mathrm{od}}\right)}
$$


where tmc - time of maneuvers in the top warehouse, $c(t m c=60 c)$; td - time for the movement of the car for the first apiary, $c(t d=20 c)$; $\mathrm{tml}$ - time of maneuvers for cutting areas, $\mathrm{c}(\mathrm{tml}$ $=90 \mathrm{c}$ ); trk - time on hauling of a rope, $\mathrm{c}$ (trk = 60c); tch - time of a chokering of switches, c (tch $=20 \mathrm{c}$ ); tpxk - time for skidding by means of a rope, $c$ (tpxk $=120 \mathrm{c})$; tcch - time of removal of choker, c (tcch $=15 \mathrm{c})$; tdn - time for moving for other apiary, c $(\operatorname{tdn}=20 \mathrm{c})$; tod - time for returns of the car for the top warehouse, c (tod $=20 \mathrm{c}$ ); tsm - time for unfolding of an arrow of the manipulator, c (tsm = 10c); tokyp - time for installation the device for fastening of the basic block (BB) in tick-borne capture (TBC) of the manipulator, $c$ (tokyp $=40 \mathrm{c}$ ); tokz - time of lowering of TBC for the earth, $c$ (tokz $=15 \mathrm{c}$ ); trkz - time of disclosure of TBC, c (trkz = 10c); tfy - TBC closing-time, c (tfy $=25 \mathrm{c}$ ); tssm - time for folding of an arrow of the manipulator, $c$ (tssm $=10 \mathrm{c}$ ).

At above the given values of the parameters substituted in a formula (4) mechanization level on subskidding $\mathrm{Ym}$.I.ss. $=0,21$, and the general level of mechanization for system of cars No. 1 is equal $\mathrm{Ym}=0,8$.

Hour productivity determines the volume of pro- duction executed during the continuous work and in the absence of any losses of time. Continuous work in practice is quite possible within an hour

$\Pi=\frac{3600 \cdot A}{T}$

therefore really to consider hour productivity as theoretical and to find it on a formula [10]

where $A$ - the volume of unit ready (processed or moved) production (a pack of trees, a switch, assortment, etc.), $\mathrm{m}^{3} ; \mathrm{T}$ - time for processing or movement of a unit of production, with; 3600 - duration of hour in seconds, c.

For calculation of productivity for a formula (2) it is necessary to paint the making T, cycle time, to carry out chronometers behind operation of machines and the equipment and to reveal statistically correct values of elements of a cycle and to calculate productivity on each operation. For example, for system of cars No. 1 hour productivity will be defined by the sum of hour productivities on each operation. Productivity of operations on a roll, a scrap of boughs, a buck and skidding will be on known formulas [10]. We find hour productivity on wood subskidding (at $A=M$ )

$\Pi_{\Pi T}=\frac{3600 \cdot M}{\frac{10^{4} \cdot V \cdot z}{L \cdot B \cdot q} \cdot\left(\frac{2 \cdot l}{U_{x}}+t_{m c}+t_{s y}\right)+\frac{2 \cdot 10^{4} \cdot V \cdot z}{L \cdot B_{\Pi} \cdot \Pi} \cdot\left(\mathrm{t}_{\mathrm{ml}}+\mathrm{t}_{\mathrm{pr}}+\mathrm{t}_{\mathrm{sm}}+\mathrm{t}_{\mathrm{okyp}}+\frac{B_{\Pi}}{U_{x}}\right)+\frac{\mathrm{l}_{\mathrm{k}}}{\mathrm{U}_{\mathrm{p}}}+\mathrm{t}_{\mathrm{ngk}}+\frac{\mathrm{l}_{\mathrm{k}}}{\mathrm{U}_{\mathrm{t}}}+\mathrm{z} \cdot\left(\mathrm{t}_{\mathrm{ch}}+\mathrm{t}_{\mathrm{cch}}\right)+\mathrm{t}_{\mathrm{okz}}+\mathrm{t}_{\mathrm{rkz}}+\mathrm{t}_{\mathrm{fy}}+\mathrm{t}_{\mathrm{ssm}}}$

where $\mathrm{M}$ - pack volume, by the skidding car, $\mathrm{m}^{3}$ $(M=V \cdot z)\left(M=3,3 m^{3}\right) ; V-$ average volume of a switch, $\mathrm{m}^{3}\left(\mathrm{~V}=0,4 \mathrm{~m}^{3}\right) ; \mathrm{z}$ - quantity of choker (under a condition one choker chokering one switch) $(z=8) ; q$ - reserved the woods on 1 hectare, $\mathrm{m}^{3} / \mathrm{ra}\left(\mathrm{q}=200 \mathrm{~m}^{3} / \mathrm{ga}\right) ; \mathrm{t}_{\mathrm{mc}}$ - time of maneuvers in the top warehouse, $c\left(t_{m c}=60 c\right) ; t m l$ - time of maneuvers for cutting areas, $c\left(t_{\mathrm{ml}}=\right.$ $90 \mathrm{c}$ ); $t_{c h}-$ time of a chokering of switches, $c$ (tch $=20 \mathrm{c}) ; \mathrm{t}_{\mathrm{cch}}$ - time of removal of choker, $\mathrm{c}$ (tcch = $15 \mathrm{c}) ; \mathrm{t}_{\mathrm{sy}}$ - time of removal by workers of the device and choker from TM hooks, $c\left(t_{s y}=15 \mathrm{c}\right)$; tpr - time of movement of workers with the device to back part of TM, c ( $\left.\mathrm{t}_{\mathrm{pr}}=20 \mathrm{c}\right)$; tsm - time for unfolding of an arrow of the manipulator, c (tsm $=10 \mathrm{c}) ; \mathrm{t}_{\mathrm{okyp}}$ - time for installation the device for fastening $\mathrm{BB}$ in TBC of the manipulator, $\mathrm{c}\left(\mathrm{t}_{\mathrm{okyp}}=\right.$ 40c); $\mathrm{t}_{\mathrm{ngk}}$ - time formation of a pack, $\mathrm{c}\left(\mathrm{t}_{\mathrm{ngk}}=10\right.$ c); $t_{\text {okz }}$ - time of lowering of TBC for the earth, $c$ $\left(\mathrm{t}_{\mathrm{okz}}=15 \mathrm{c}\right) ; \mathrm{t}_{\mathrm{rkz}}$ - time of disclosure of TBC, $\mathrm{c}\left(\mathrm{t}_{\mathrm{rkz}}\right.$ $=10 \mathrm{c}) ;$ tfy - TBC closing-time, $c\left(t_{f y}=25 c\right) ; t s s m$
- time for folding of an arrow of the manipulator, $c\left(t_{s s m}=10 c\right) ; U_{x}-$ average speed of the skidding car without freight, $\mathrm{m} / \mathrm{c}\left(\mathrm{U}_{\mathrm{x}}=0,8 \mathrm{~m} / \mathrm{c}\right)$; $\mathrm{U}_{\mathrm{p}}$ - average speed of the movement of a skidding rope without freight, $\mathrm{m} / \mathrm{c}\left(U_{\mathrm{p}}=0,5 \mathrm{~m} / \mathrm{c}\right)$; $U \mathrm{t}$ - average speed of the movement of a rope with freight, $\mathrm{m} / \mathrm{c}\left(U_{\mathrm{t}}=2 \mathrm{~m} / \mathrm{c}\right) ; \mathrm{I}$ - distance from the top warehouse to the first apiary, $m(I=b / 2+c, b-$ apiary width, $\mathrm{m} ; \mathrm{c}-$ distance from the top warehouse to an apiary, $m)(I=35 \mathrm{~m})$; I $\mathrm{k}$ - average length of hauling of a rope on an apiary, $\mathrm{m}(\mathrm{IK}=80 \mathrm{~m})$; $\mathrm{L}$ - allotment length $\mathrm{m}(\mathrm{L}=400 \mathrm{~m}) ; \mathrm{B}$ - allotment width (extent along a mustache), $\mathrm{M}(B=200 \mathrm{~m})$. At above the given values of the parameters substituted in a formula (8) productivity on subskidding is received $\Pi \Pi т=22 \mathrm{~m}^{3} /$ hour.

Time spent by cars for technological process per $1 \mathrm{~m} 3$ processed wood on each operation, are determined as private from division of time of one hour into hour productivity by each operation. 
Table 1: Numerical values of criteria of an assessment of technological processes

\begin{tabular}{|c|c|c|c|c|c|c|c|}
\hline $\begin{array}{l}\text { № } \\
\text { п/п }\end{array}$ & Scheme & Operation & $\begin{array}{c}\text { Hour } \\
\text { productivity, } \\
\text { m3/hour }\end{array}$ & $\begin{array}{l}\text { Expenses } \\
\text { of time } \\
\text { for } 1 \mathrm{~m} 3 \text {, } \\
\mathrm{m} 3 / \text { mines }\end{array}$ & $\begin{array}{c}\text { Mechanization } \\
\text { level }\end{array}$ & $\begin{array}{c}\text { Criterion of } \\
\text { power } \\
\text { consump- } \\
\text { tion, } \\
\mathrm{kW} \cdot \mathrm{h} / \mathrm{m} 3 \\
\end{array}$ & $\begin{array}{l}\text { Environmental } \\
\text { friendliness } \\
\text { coefficient }\end{array}$ \\
\hline \multirow{5}{*}{ 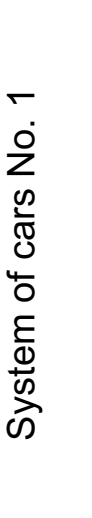 } & \multirow{5}{*}{ 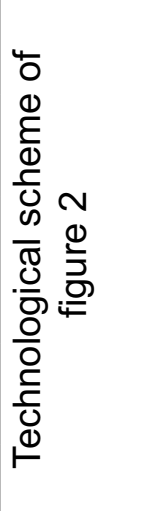 } & $\begin{array}{c}\text { Felling, } \\
\text { log bunching }\end{array}$ & 20,7 & 20,7 & 1 & 0,066 & \multirow[t]{5}{*}{0,1729} \\
\hline & & $\begin{array}{c}\text { Subskidding } \\
\text { of trees }\end{array}$ & 22 & 11 & 0,21 & 0,21 & \\
\hline & & $\begin{array}{c}\text { Limb } \\
\text { chopping, } \\
\text { bucking } \\
\end{array}$ & 25,44 & 25,44 & 1 & 0,377 & \\
\hline & & $\begin{array}{c}\text { Suspended } \\
\text { skidding }\end{array}$ & 11,28 & 11,28 & 1 & 0,224 & \\
\hline & & Total & & 13,3 & 0,8 & 0,877 & \\
\hline \multirow{6}{*}{ 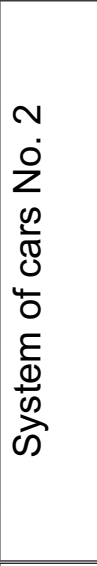 } & \multirow{6}{*}{ 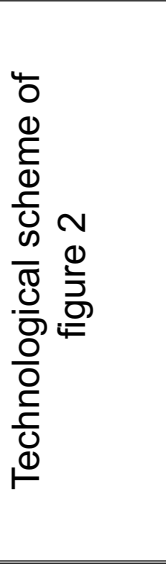 } & $\begin{array}{l}\text { Felling, log } \\
\text { bunching }\end{array}$ & 20,7 & 20,7 & 1 & 0,066 & \multirow[t]{6}{*}{0,1729} \\
\hline & & $\begin{array}{c}\text { Limb } \\
\text { chopping }\end{array}$ & 17 & 17 & 0,18 & 0,02 & \\
\hline & & $\begin{array}{l}\text { Subskidding } \\
\text { of } \\
\text { tree-length } \\
\end{array}$ & 22 & 11 & 0,21 & 0,21 & \\
\hline & & Bucking & 9,6 & 9,6 & 0,18 & 0,02 & \\
\hline & & $\begin{array}{l}\text { Suspended } \\
\text { skidding }\end{array}$ & 11,28 & 11,28 & 1 & 0,224 & \\
\hline & & Total & & 20,65 & 0,51 & 0,52 & \\
\hline \multirow{5}{*}{$\begin{array}{l}m \\
\dot{0} \\
z \\
0 \\
\frac{0}{0} \\
0 \\
\frac{0}{0} \\
\frac{c}{0} \\
\frac{1}{\omega} \\
\text { के }\end{array}$} & \multirow{5}{*}{ 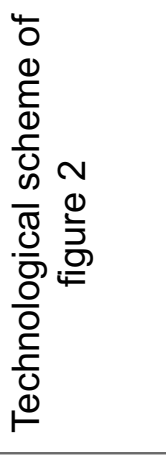 } & Felling & 10,23 & 10,23 & 0,15 & 0,005 & \multirow[t]{5}{*}{0,0325} \\
\hline & & $\begin{array}{c}\text { Subskidding } \\
\text { of trees }\end{array}$ & 22 & 11 & 0,21 & 0,21 & \\
\hline & & $\begin{array}{c}\text { Limb } \\
\text { chopping, } \\
\text { bucking } \\
\end{array}$ & 25,44 & 25,44 & 1 & 0,377 & \\
\hline & & $\begin{array}{c}\text { Suspended } \\
\text { skidding } \\
\end{array}$ & 11,28 & 11,28 & 1 & 0,224 & \\
\hline & & Total & & 16,3 & 0,59 & 0,816 & \\
\hline \multirow{3}{*}{ 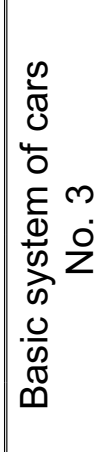 } & \multirow{3}{*}{ 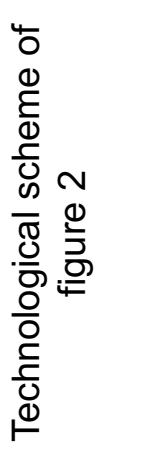 } & $\begin{array}{l}\text { Felling, limb } \\
\text { chopping, } \\
\text { bucking } \\
\text { Hypro } 755+ \\
\text { FG45 } \\
\end{array}$ & 18,6 & 18,6 & 1 & 0,476 & \multirow[t]{3}{*}{0,1729} \\
\hline & & $\begin{array}{c}\text { Suspended } \\
\text { skidding Hy- } \\
\text { pro HV14 } \\
\end{array}$ & 11,5 & 11,5 & 1 & 0,568 & \\
\hline & & Total & & 8,4 & 1 & 1,044 & \\
\hline
\end{tabular}


The total time spent by systems of cars for technological process per $1 \mathrm{~m} 3$, summation of similar expenses on all operations is defined in the way.

Numerical values of criteria of an assessment of technological processes for systems of cars No. 1, No. 2, are presented to No. 3 in tab. 1. As basic option the system of cars consisting of a harvester, the including DBM Hypro 755 from GCD FG45 and a forwarder of Hypro HV14 which criteria are also presented in tab. 1 is accepted.

The numerical values presented in tab. 1 showed that in system of cars No. 1 of expense of time for $1 \mathrm{~m} 3$ 13,3 m3/mines, mechanization level - 0,8, power consumption - 0,877 kW/h/m3, environmental friendliness coefficient $-0,1729$. In system of cars No. 2 of expense of time for $1 \mathrm{~m} 3$ 20,65 m3/mines, mechanization level $-0,51$, power consumption - 0,52 kW/h/m3, environmental friendliness coefficient $-0,1729$. In system of cars No. 3 of expense of time for 1 m3 16,3 m3/mines, mechanization level - 0,59, power consumption - 0,816 kW·h/m3, environmental friendliness coefficient $-0,0325$.

\section{CONCLUSIONS}

1. On a cumulative assessment by the stated criteria it was expedient system of cars No. 2 which surpasses system of cars No. 1 in criterion of power consumption and expenses of time for $1 \mathrm{~m} 3$, but concedes to them on mechanization level.

2. The offered techniques and examples of calculations allow to receive numerical characteristics above the listed criteria. They are recommended for use at the enterprises preparation of wood in which is carried out in extreme conditions: in burned forests, on the remoistened soil, windfalls, etc.

3. At a choice of systems of cars for specific extreme conditions of logging not all compared systems can be used, for example, in the rehumidified territories that also limits degree of their applicability.

\section{REFERENCES}

1) Kochegarov, V. G. Technology and car of cutting area operations: studies. grant / V. G. Kochegarov, Yu. A. Beat, V. N. Menshikov. Moscow: Forest industry, 1990. - 392 pages.

2) Patent for the useful model No. 112592 Russian Federation, MPKA01G23/00. The car for skidding / Shirnin Yu.A, Shirnin A.YU., Egorov A.V., Zverev I.V., Morzhanov A.Yu.; applicant and patent holder the Mari state. those. university - 2010129675/13; zayavl. 15.07.2010; opubl. 20.01.2012, Bulletin No. 2.

3) Patent No. 2357407 Russian Federation, $\mathrm{MCl} 7 \mathrm{~A} 01 \mathrm{G} 23 / 00$. A way and the car for skidding / Shirnin Yu.A, Shirnin A.YU., Bogatyrev E.A., Akazova O. V.; applicant and patent holder the Mari state. those. university. - 2007122910/12; zayavl. 18.06.2007; opubl. 10.06.2009, Bulletin No. 8. - 5s.

4) Shirnin, Yu. A. Complex development of sites of forest fund / Yu. A. Shirnin//News of higher education institutions. Forest magazine. - 2002. - No. 4. - Page 89-95.

5) Shirnin, Yu. A. Modeling of processes of preparation of the sorted trees and switches: monograph/Yu. A. Shirnin. - Krasnoyarsk: Publishing house Krasnoyar. un-that, 1992. - 204 pages.

6) Shirnin, YU.A. Modeling of energy consumption of adaptive and modular systems of cars at the combined wood skidding / Yu. A. Shirnin, A. Yu. Shirnin//the MGUL Bulletin. Forest messenger. - 2013. - No. 3. - Page 166-175.

7) Shirnin Yu. A. Modeling of energy consumption at the combined wood skidding by adaptive and modular cars / Shirnin Yu. A., Shirnin A. Yu., Zverev I. V., Morzhanov A. Yu. Messenger of MARGTU. It is gray.: Wood. Ecology. Environmental management. - 2011. - No. 3. Page 50-57.

8) Shirnin Yu.A. Solutions of problems of logging in extreme conditions / Yu.A. Shirnin, A.Yu. Shirnin//Bulletin of Volga region state technological university. Wood. Ecology. Environmental management. - 2014. - No. 2. - Page 46-54.

Paper sent to revision: 21.11.2015.

Paper ready for publication: 26.01.2016. 